\author{
Przemysław Sołga \\ (Uniwersytet Pedagogiczny w Krakowie) \\ https://orcid.org/0000-0002-0670-8857
}

\title{
Państwo laickie i Kościół: Uwagi na temat książki Urszuli Wasilewicz, Systemy relacji między Kościołem katolickim i Francja. Studium historyczno-prawne, Stowarzyszenie Absolwentów i Przyjaciół Wydziału Prawa Katolickiego Uniwersytetu Lubelskiego, Lublin 2017, ss. 263
}

The Secular State and the Church: Remarks on the Monograph "Systemy relacji między Kościołem katolickim i Francja. Studium historyczno-prawne" ["Relation Systems between the Catholic Church and France. A Historical and Legal Study"] by Urszula Wasilewicz, Stowarzyszenie Absolwentów i Przyjaciół Wydziału Prawa Katolickiego Uniwersytetu Lubelskiego, Lublin 2017, pp. 263

\section{STRESZCZENIE}

Motywem do napisania niniejszego tekstu było wiele kontrowersyjnych stwierdzeń Autorki opiniowanej książki. W artykule oceniono publikację Urszuli Wasilewicz, biorąc pod uwagę takie aspekty, jak jej konstrukcja, podstawa źródłowa i zawartość merytoryczna. Zwrócono uwagę na istotne braki w pracy oraz podjętego polemikę z niektórymi stwierdzeniami Urszuli Wasilewicz. Autor zastosował metodę analizy i syntezy oraz metodę indywidualnych przypadków. W ten sposób ukazano bezzasadność niektórych konstatacji Autorki.

Słowa kluczowe: państwo, Kościół katolicki, relacje, system prawny

Kościół katolicki we Francji niewątpliwie przeżywa obecnie kryzys, a jego źródła sięgają na pewno daleko poza XX w. Napięte relacje państwo-Kościół w tym kraju, wynikające po części ze skomplikowanej rzeczywistości społecznej i religijnej, wielokrotnie zdominowały w nim życie polityczne, a co za tym idzie kwestie prawnoustrojowe, odnoszące się także do stosunku państwa wobec Kościoła. Opisanie tego procesu w ujęciu 
historycznym jest niewątpliwie karkołomnym zadaniem, wymagającym nie tylko wiedzy historycznej, ale także tej z zakresu nauk prawnych i politologii. Podjęła się go Urszula Wasilewicz, młoda badaczka związana z Katolickim Uniwersytetem Lubelskim.

Recenzowana książka jest publikacją dysertacji doktorskiej, obronionej na KUL w 2016 r. Jej Autorka związała swoją pracę zawodową z macierzystą uczelnią i jest obecnie pracownikiem Wydziału Prawa, Prawa Kanonicznego i Administracji KUL. Zajmuje się naukowo prawem kanonicznym i jego historia zaś temat podjęty w opiniowanej książce znalazł także odzwierciedlenie $w$ jednym $z$ opublikowanych przez nią artykułów ${ }^{1}$. Wiedza U. Wasilewicz z zakresu prawa kanonicznego była na pewno wielkim atutem przy pisaniu dysertacji.

Tematyka, którą Autorka podjęła w recenzowanej publikacji jest na pewno bardzo szeroka, jednak nie doczekała się jeszcze w Polsce rzetelnego, syntetycznego opracowania. Trudno jednak nazwać książkę U. Wasilewicz synteza, głównie ze względu na jej stosunkowo niewielką - jak na niniejszą tematykę - objętość, zwłaszcza w odniesieniu do pierwszych rozdziałów, w których historię relacji państwo-Kościół we Francji nakreśliła raczej ogólnikowo. We Wstępie Autorka słusznie konstatuje: „[...] do tej pory $\mathrm{w}$ polskiej literaturze kanonistycznej i z zakresu prawa wyznaniowego nie został podjęty ten problem $\mathrm{w}$ tak szerokim zakresie, zarówno jeśli chodzi o czasookres historyczny, jak również rozpiętość geograficzną i merytoryczną" (s. 6). Określenie „rozpiętość merytoryczna” jest dosyć udziwnione, choć domyślam się, że U. Wasilewicz chodziło w tym przypadku o zakres ram tematycznych pracy. Te ostatnie są ujęte prawidłowo i pod względem merytorycznym, na który wskazuje Autorka, przynajmniej z samego założenia wyczerpują temat w sposób dostateczny.

Podtytuł pracy sugeruje, że ma ona charakter "studium historyczno-prawnego" i w zasadzie dotyczy historii stosunków państwo-Kościół we Francji. Główny nacisk położono jednak na analizę prawną. Ta ostatnia została moim zdaniem słabo wyeksponowana w przypadku pierwszego rozdziału, zwłaszcza jeśli chodzi o najdawniejsze dzieje Francji. Zwracam tutaj uwagę na bardzo szerokie ramy chronologiczne publikacji - Autorka uznała bowiem, że stosowne jest rozpoczęcie wywodów dotyczących podjętej tematyki już od chrztu przyjętego przez Chlodwiga w $496 \mathrm{r}$. Te najdawniejsze czasy Francji zostały jednak ujęte raczej w formie studium historycznego; $\mathrm{U}$. Wasilewicz nie zagłębia się zbytnio w analizę powstałych w tamtych czasach przepisów prawnych (mam tutaj na myśli

1 U. Wasilewicz, Organizacja funkcjonowania Kościoła we francuskim porzadku prawnym, „Kościół i Prawo” 2013, 2, s. 197-208. 
rzecz jasna spisane za czasów Chlodwiga prawo salickie). Pierwsze partie pracy to przede wszystkim opis historii Kościoła we Francji.

W bibliografii pracy Autorka wymienia źródła, które mają charakter głównie aktów normatywnych. Źródeł archiwalnych nie ma w ogóle, brakuje też odniesień do francuskiej publicystyki, zarówno katolickiej, jak i politycznej. Po części jest to dla mnie zrozumiałe, ponieważ U. Wasilewicz dokonała analizy omawianej tematyki z punktu widzenia kanonisty i prawnika, a nie historyka, taki też chyba był jej cel, skoro we Wstępie wskazuje na zastosowanie dwóch metod badawczych charakterystycznych dla pracy prawników i kanonistów, a mianowicie historyczno-prawnej i dogmatyczno-prawnej (s. 9). Metoda analizy i syntezy innych rodzajów źródeł byłaby jednakże cennym uzupełnieniem dla lepszego zrozumienia poruszanych zagadnień; relacje państwowo-kościelne angażują przecież różne warstwy społeczne, nie wynikają tylko z określonych postaw, ale też je kreują i to wszystko wywiera wpływ na kształt regulacji prawnych, wyrażonych w dokumentach, które Autorka zdecydowała się poddać swojej analizie. Zrozumienie znaczenia tych dokumentów bez poszerzenia kontekstu o kategorie historyczne i społeczno-polityczne jest czasami niemożliwe, a analiza samych ich treści przy tylko zdawkowym przytaczaniu historycznych okoliczności ich powstania moim zdaniem mija się z celem, tym bardziej że - przypomnijmy - w książce, zgodnie z założeniem U. Wasilewicz, mamy mieć do czynienia z analizą historyczno-prawna, a nie tylko prawną.

Spośród opracowań poruszających zagadnienie sytuacji Kościoła podczas Wielkiej Rewolucji Francuskiej Autorka przywołuje opracowanie Adama Wielomskiego², jednak odniesienie się do publicystycznej pracy Jerzego Roberta Nowaka ${ }^{3}$ również moim zdaniem byłoby wskazane. Urszula Wasilewicz mogłaby podjąć próbę naukowej weryfikowalności zawartych tam tez. Jeszcze bardziej zasadne byłoby to w przypadku książki Henryka Łakomego pt. Państwo i Kościót we Francji. Historia i współczesność ${ }^{4}$ - pracy, z niewiadomych mi powodów, pominiętej przez Autorkę. Podejmuje ona $\mathrm{w}$ zasadzie ten sam temat, co recenzowana publikacja, tyle że przy znacznie węższych ramach chronologicznych. Być może nie jest to opracowanie stricte naukowe - choć poddane ocenie przez dwóch recenzentów wydawniczych - jednakże na pewno godne uwagi. H. Łakomy prezentuje w swojej książce wiele kontrowersyjnych tez, a U. Wasilewicz

2 A. Wielomski, Kościót w cieniu gilotyny. Katolicyzm francuski wobec Rewolucji (17891815), Warszawa 2009.

3 J.R. Nowak, Kościół a Rewolucja Francuska, Szczecinek 1999.

4 H. Łakomy, Państwo a Kościót we Francji. Historia i wspótczesność, Kraków 1999. 
jest na pewno osobą kompetentną do tego, aby wejść z nim w polemikę. Uważa on na przykład, że „w wyniku rozdziału od państwa, Kościół we Francji tylko zyskał. Został osłabiony materialnie, ale odróżnił się religijnie i skierował aktywność na doczesne trudności ludu Bożego"5. Stwierdzenie to jest przekłamane zarówno z teologicznego, jak i socjologicznego punktu widzenia.

W konstrukcji opracowania Urszuli Wasilewicz niewątpliwie uwagę przykuwa to, że pierwszy rozdział zajmuje niemal połowę całej treści zasadniczej pracy i dotyczy sytuacji politycznej Kościoła we Francji aż do końca XIX w. Miałoby to moim zdaniem większy sens, gdyby ów rozdział nie miał charakteru stricte historyczno-opisowego, tak jak jest w tym przypadku, ale stanowił dogłębną analizę sytuacji prawnej Kościoła we Francji, tymczasem Autorka jej nie dokonuje. Przedstawia na przykład założenia prawne konkordatu zawartego przez Napoleona Bonapartego (s. 61-63), ale już nie dokonuje jego analizy oczyma prawnika czy kanonisty. Informacje zawarte $\mathrm{w}$ tym rozdziale można $\mathrm{w}$ zasadzie $\mathrm{z}$ łatwością znaleźć w powszechnie dostępnych książkach historycznych, także w podręcznikach do historii. Urszula Wasilewicz już we Wstępie podkreśla, że „relacje między władzą świecką i religijną w danym państwie zależą od czynników zarówno historycznych, społecznych, kulturowych, jak i politycznych" (s. 5). Po lekturze książki odniosłem wrażenie, że Autorka sama nie zastosowała się do wytyczonych przez siebie zasad, bo jak w pierwszym rozdziale opisuje czynniki historyczne, społeczne i kulturowe, nie zagłębiając się $\mathrm{w}$ analizę prawną aktów normatywnych, tak w dwóch pozostałych postępuje dokładnie odwrotnie, to znaczy skupia się niemal wyłącznie na samej ich analizie, czy też raczej na przytaczaniu zawartych w nich wytycznych, bez uwzględnienia szerszego kontekstu.

Praca ogółem składa się z trzech zasadniczych rozdziałów. W rozdziale pierwszym opisano stosunki państwo-Kościół we Francji, biorąc pod uwage wspomniany szeroki zakres chronologiczny, obejmujący lata 4961905. Rozdział drugi odnosi się ściśle do ustawy o świeckości państwa z 1905 r. i opisuje szczegółowo system separacji wrogiej, jeśli chodzi o stosunek państwa do Kościoła, wynikający głównie z tejże ustawy. Autorka uwzględniła $\mathrm{w}$ nim różne ramy geograficzne, podnosząc słusznie, że w niektórych regionach Francji te relacje rysowały się różnie. W ostatnim, trzecim, rozdziale podniesiono natomiast kwestie systemu państwa wyznaniowego w regionach należących do Francji, takich jak Gujana Francuska, Nowa Kaledonia, a także te o charakterze wyspiarskim - Wallis i Futura, Saint Pierre i Miquelon, Majotta i Polinezja Francuska. Książkę

5 Ibidem, s. 150. 
na końcu wzbogacono także o załączniki, na które składają się wybrane dokumenty kościelne i akty prawne - w języku francuskim i ich transkrypcją na język polski. Szkoda, że tytuły tych dokumentów są podane wyłącznie w języku francuskim - jest to pewna niekonsekwencja ze strony Autorki, mogąca przysparzać trudności czytelnikom nieznającym tego języka. Natomiast godne podkreślenia jest to, że w pracy znalazło się także streszczenie oraz spis treści w języku francuskim, co ma wskazywać, że jest ona skierowana także do francuskojęzycznych badaczy poruszanego zagadnienia.

Autorkę bulwersuje powszechny pogląd, że we Francji ma miejsce tzw. separacja wroga, jeśli chodzi o model państwa świeckiego, ponieważ w jej terytoriach zamorskich występuje system prawa wyznaniowego, nieco inne są też rozwiązania prawne na terenie Alzacji i Lotaryngii (s. 6-7). Moim zdaniem, przy całościowym ujęciu problemu, tamte przypadki nie mają większego znaczenia, ponieważ dotyczą stosunkowo niewielkiego obszaru i są czymś odosobnionym. Nie przekonuje mnie także stwierdzenie U. Wasilewicz, że zdecydowała się na ich szczegółowe opisanie ze względu na to, iż mają swoje uzasadnienie „społeczne, historyczne i prawne" (s. 7). Przeciętny człowiek - nawet ten zajmujący się naukowo poruszanymi zagadnieniami - myśląc o stosunku państwa francuskiego do Kościoła ma przed oczyma wizję niemal awersji religijnej, przejawiającej się w kompletnym usunięciu religii z życia społeczno-politycznego i raczej nie ma dla niego większego znaczenia to, że dwa departamenty $\mathrm{w}$ Lotaryngii stosują $\mathrm{w}$ tym zakresie nieco inne rozwiązania, ponieważ polityka Francji na szczeblu federalnym jest całkowicie areligijna i to będzie punktem odniesienia dla jego dociekań. Jeśli z kolei Autorka chciała podać wzorcowe przykłady systemu relacji państwo-Kościół do zastosowania $\mathrm{w}$ innych krajach - bo na to też wskazuje, zaznaczając, że się tego nieumiejętnie nie robi - to chciałbym podkreślić, że w wielu miejscach na świecie są one o wiele lepsze.

Urszula Wasilewicz stwierdza, że „wykształcenie się cezaropapizmu wynikało z głęboko zakorzenionych zasad totalitaryzmu Cesarstwa Rzymskiego, w którym cesarz nosił tytuł pontifex maximus i jednoczył w sobie władze państwową i religijna, a ius sacrum stanowiło część ius publicum" (s. 17). Nie ujmując Autorce racji, pragnę podkreślić, że wyraziła się dosyć nieprecyzyjnie, bowiem używanie w tym przypadku określenia „totalitaryzm” jest na pewno niestosowne. Pryncypat nie był postrzegany przez współczesnych, nawet przez samych rządzących, jako forma monarchii, choć w istocie faktycznie nią był. Cesarz rzymski był jednak raczej tym, który sprawował kult aniżeli tym, którego się tym kultem obdarza nawet przydomek August nie nadawał mu takiej rangi, choć poszczególni 
imperatorzy w różny sposób podchodzili do tych kwestii. Istotna zmiana zaszła dopiero po wprowadzeniu dominatu przez Dioklecjana i po tej linii w dużym stopniu szli następnie cesarze bizantyjscy, a w ślad za nimi carowie rezydujący w Moskwie - „Trzecim Rzymie”. Niewykluczone, że w tym ostatnim przypadku określenie „totalitaryzm” byłoby bardziej na miejscu, a współczesna mentalność Rosjan i ich stosunek do władzy państwowej być może są także pokłosiem tamtejszych czasów ${ }^{6}$.

Podnosząc kwestię zmian w zakresie filozofii prawa, jakie zaszły w wyniku Wielkiej Rewolucji Francuskiej, Autorka zauważa, że „,władza świecka przestała uznawać Boga jako źródło swojej władzy. [...] Wprowadzone przez Rewolucję hasło pochodzenia władzy «z ludu i dla ludu» sprawiło, że przestano potrzebować autorytetu kościelnego dla legitymizowania władzy" (s. 86). Moim zdaniem jednak istotna była tutaj nie tylko kwestia legitymizacji władzy, ale też to, że sfera sacrum została niemalże zupełnie wyrugowana z polityki. Nie tylko "sojusz tronu i ołtarza" stracił odtąd jakiekolwiek znaczenie, ale zmieniło się także samo pojmowanie władzy, której ceremoniał w żadnym stopniu nie odnosił się już do kwestii związanych $z$ religią. Warto jednak przytoczyć w tym miejscu trafne spostrzeżenie Moniki Milewskiej, która zauważa, że nawet areligijna Wielka Rewolucja Francuska nosiła pewne znamiona sacrum - na przykład egzekucje były kojarzone z obrzędami religijnymi; znane było wówczas powiedzenie: „[...] pójdźmy do stóp wielkiego ołtarza, by zobaczyć, jak odprawiana jest czerwona msza"7 ${ }^{7}$. Człowiek jest z natury istotą religijną i żadne rewolucje nie są w stanie tego wykorzenić.

Powyższą uwagę można także odnieść do innych stwierdzeń Autorki. Podnosi ona na przykład, że „w relacjach Napoleona do Kościoła katolickiego można stosować określenie cezaropapizm” (s. 61). Moim zdaniem jest ono bardzo kontrowersyjne. Cezaropapizm bizantyjskich cesarzy był czymś zupełnie odmiennym, przede wszystkim dlatego, że łączył się ściśle ze sferą sacrum, z której napoleonizm był w istocie obdarty. Wszelkie ceremonialne zaangażowanie Kościoła w jego życie polityczne, takie jak obecność papieża na koronacji Napoleona, były w istocie farsą i służyły wyłącznie celom propagandowym, co zresztą zauważa w swojej książce sama U. Wasilewicz. Napoleon wszakże otwarcie podkreślał, że jest dzieckiem Wielkiej Rewolucji Francuskiej, a ta z kolei z wartościami chrześcijańskimi nie miała nic wspólnego. Godne podkreślenia jest też to,

6 Zob. H. Kryzheuski, Podstawowe cechy mentalności narodowej, wptywajace na sfere religijno-moralna współczesnej Rosji, „Studia Teologiczne Białystok - Drohiczyn - Łomża” 2010, 28 , s. 395-410.

7 M. Milewska. Ocet i łzy. Terror Wielkiej Rewolucji Francuskiej jako doświadczenia traumatyczne, Gdańsk 2001, s. 9. 
że w niektórych biografiach „Cesarza Francuzów” można znaleźć informację o tym, iż w młodości zetknął się $\mathrm{z}$ masonerią i całkiem możliwe, że wywarło to wpływ na jego stosunek do religii. Na przekór tym informacjom warto też dodać, że Napoleon tuż przed śmiercią przyjął ostatnie namaszczenie z rąk katolickiego kapłana.

W innym miejscu Autorka konstatuje: „,[...] nie należy jednak zapominać, że na każdym etapie historii Francji, gdy prowadzone były represje okrutne i niesprawiedliwe wobec Kościoła, jednocześnie następowała odnowa moralna i religijna. Tak było w przypadku św. Joanny D’Arc, św. Małgorzaty, objawień maryjnych w Lourdes i La Salette, czy ruchu ralliement" (s. 86). Niniejsze stwierdzenie jest moim zdaniem dosyć naiwne i nieznajdujące odzwierciedlenia w faktach. Objawienia św. Małgorzaty Alacoque przywodzą mi nieodparcie na myśl zapiski św. siostry Łucji dos Santos, wedle Kościoła katolickiego wizjonerki z Fatimy, która wspominała (powołując się na objawienie samego Chrystusa), że niespełnienie przez króla Francji w odpowiednim czasie próśb św. Małgorzaty dotyczących upowszechnianego przez nią kultu doprowadziły do urzeczywistnienia okropieństw Wielkiej Rewolucji Francuskiej. Nic mi nie wiadomo też o tym, jakoby ten kult był we Francji w sposób szczególny upowszechniony. Natomiast postać Joanny D’Arc miała dla Francuzów znaczenie bardziej polityczne aniżeli religijne. Wymowny jest też fakt, że jej beatyfikacja i kanonizacja miały miejsce dopiero w XX w. Urszula Wasilewicz mogła się jednak powołać na XIX-wieczną postać Kościoła, która ewidentnie wywierała wpływ na ludność Francji. Był nim niewątpliwie św. Jan Maria Vianney, który osobiście doświadczył okrucieństwa Wielkiej Rewolucji Francuskiej. W ciągu całego swojego życia wyspowiadał ponad milion Francuzów i szacuje się, że gdyby przeżył jeszcze kilka lat, wszyscy mieszkańcy Francji odprawiliby u niego spowiedź. Czy to jednak wpłynęło w sposób istotny na francuską mentalność? Objawienia maryjne w Lourdes, uznane przez Kościół za autentyczne, także nie przyniosły spektakularnych metamorfoz w aspekcie stosunku mieszkańców Francji do religii. Większość współczesnych pątników to cudzoziemcy. Emil Zola był podobno świadkiem cudu w tym miejscu, co jednakże nie zmieniło jego ateistycznego i antyklerykalnego światopoglądu, który zresztą wyeksponował w swojej powieści pt. Lourdes, wyszydzającej tamtejszych pielgrzymów. Nic mi też nie wiadomo na temat tego, jaka to "odnowa religijna i moralna" zdaniem U. Wasilewicz zapanowała we Francji po objawieniach maryjnych w La Salette; współcześnie przeciętny Francuz zapewne o nich nawet nie słyszał. Żadnej odnowy nie zaprowadził też zainicjowany przez Leona XIII w encyklice Au milieu de solicitudes „ruch ralliement”, mający wymiar 
polityczny, a pogrzebany całkowicie przez wprowadzenie kilka lat później ustawy o rozdziale Kościoła od państwa. Przychylałbym się raczej do stwierdzenia, że jest dokładnie odwrotnie, niż pisze Autorka: represje wobec Kościoła przyczyniały się we Francji do wzrostu nastrojów antyklerykalnych, a ruchy znajdujące się na przeciwległym biegunie miały raczej pomniejsze znaczenie i na pewno nie wywarły istotnego wpływu na francuską mentalność.

Pisząc o ministrze oświecenia publicznego Julesie Ferrym i zainicjowanej przez niego reformie oświaty $\mathrm{w}$ duchu świeckim $\mathrm{z}$ lat siedemdziesiątych i osiemdziesiątych XIX w., U. Wasilewicz nie dodaje informacji, że był on członkiem francuskiej loży masońskiej Wielki Wschód, a z przekonania zagorzałym ateistą i pozytywistą ${ }^{8}$. Niestety, podobnie jak Marta Wójtowicz-Wcisło w przypadku historii relacji państwo-Kościół w Meksyku' ${ }^{9}$, Autorka przemilczała kwestię masonerii i jej wpływu na życie społeczno-polityczne Francji, tymczasem Wielki Wschód Francji wywierał i wciąż wywiera istotny wpływ na tamtejsze prawodawstwo.

Urszula Wasilewicz wspomina w pierwszych partiach swojej pracy o postaci Karola Młota ${ }^{10}$ i jego zasługach, jeśli chodzi o odparcie inwazji muzułmańskiej (bitwa pod Poitiers - s. 17). Frankoński władca zapewne nie spodziewał się, że wyznawcy religii proroka Mahometa będą niegdyś stanowić ponad 6\% ludności jego kraju i cieszyć się względną swobodą religijną. Zagadnienie to Autorka jednak zupełnie pominęła w swojej książce i szkoda, że śladem H. Łakomego nie dokonała ogólnikowego studium porównawczego, jeśli chodzi o sytuację prawną muzułmanów we Francji. Ten ostatni zauważa, że „kościół [sic!] katolicki zgodnie z soborową zasadą dialogu islamsko-chrześcijańskiego, odstępuje (także nieodpłatnie) muzułmańskim grupom eklezjalnym, własne nieużywane obiekty sakralne"11. Tymczasem nie do pomyślenia jest sytuacja odwrotna - muzułmanin zazwyczaj nie pozwoli chrześcijaninowi nawet dotknąć Koranu. A jeśli chodzi o meczety, to w świecie muzułmańskim, zwłaszcza w krajach arabskich, panuje zasada mówiąca, że w miejscu, w którym ongiś stał meczet - nawet jeśli nie ma już po nim śladu - absolutnie nie można wybudować żadnego innego budynku. Tymczasem zsekularyzowane katolickie

8 K. Orzeszyna, Świeckość szkoły a nauczanie religii we Francji, „Roczniki Nauk Prawnych" 2004, 14, 4, s. 5.

9 Zob. M. Wójtowicz-Wcisło, Dwie władze. Studium z dziejów relacji państwo-Kościót w Meksyku, Kraków 2016.

10 Autorka używa nazwy Karol Martel, która jest moim zdaniem błędna, ponieważ w polskiej transkrypcji przytaczany frankoński władca znany jest jako Karol Młot. Konsekwentnie można używać francuskojęzycznego określenia Charles Martel.

11 H. Łakomy, op. cit., s. 108. 
kościoły zamienia się czasem we Francji na dyskoteki i wielka szkoda, że Autorka nie nawiązała do tego w podrozdziale zatytułowanym Budynki i miejsca kultu (s. 124-131).

Urszula Wasilewicz dodaje też, że „relacje między państwem i Kościołem na terytorium Republiki Francuskiej są przykładem modelu państwa świeckiego w wersji separacji wrogiej. [...] Za pozytywny aspekt tego systemu należy wskazać zakaz dyskryminacji ze względu na przekonania religijne i światopoglądowe oraz dostęp do wszystkich zawodów" (s. 160-161). Czy zatem w krajach, w których takiej separacji nie ma, dyskryminacja ze względu na przekonania religijne i światopoglądowe jest zawsze prawnie usankcjonowana, a przedstawiciele poszczególnych grup społecznych czy religijnych mają odciętą drogę do niektórych zawodów? Krajem wybitnie katolickim jest przecież dla przykładu Polska i pomimo braku „separacji wrogiej” w stosunku do Kościoła u nas zjawiska tego typu na pewno nie występują. Być może Autorka chciała w istocie przedstawić nieco inną sentencję, a tylko nieprecyzyjnie się wyraziła. Separacja wroga, z jaką mamy do czynienia we Francji, na pewno nie musi być jedynym warunkiem, by w danym kraju zapanowała szeroko pojęta tolerancja.

Moja ocena książki Urszuli Wasilewicz nie jest jednoznaczna, jednak w ostatecznej konkluzji zdecydowanie pozytywna. Autorka wykazała się niewątpliwie dużą wiedzą i umiejętnością syntetyzowania w zakresie prawa kanonicznego oraz jego historii. Być może lepszym rozwiązaniem byłoby skupienie się w pracy na samej kwestii ustawy z 1905 r. o rozdziale Kościoła od państwa we Francji. Ten wątek zajmuje w monografii najwięcej miejsca, a pozostałe partie moim zdaniem wymagają istotnych uzupełnień. Nic nie stoi na przeszkodzie, aby Autorka dokonała ich przy kolejnych wydaniach książki, na co też zresztą bardzo liczę z uwagi na niezwykle interesujący temat, który podjęła.

\section{BIBLIOGRAFIA (REFERENCES)}

Kryzheuski H., Podstawowe cechy mentalności narodowej, wptywajace na sfere religijno-moralna wspótczesnej Rosji, „Studia Teologiczne Białystok - Drohiczyn - Łomża” 2010, 28.

Łakomy H., Państwo a Kościót we Francji. Historia i wspótczesność, Kraków 1999.

Milewska M., Ocet i łzy. Terror Wielkiej Rewolucji Francuskiej jako doświadczenia traumatyczne, Gdańsk 2001.

Nowak J.R., Kościół a Rewolucja Francuska, Szczecinek 1999.

Orzeszyna K., Świeckość szkoły a nauczanie religii we Francji, „Roczniki Nauk Prawnych” 2004, 14, 4.

Wasilewicz U., Organizacja funkcjonowania Kościoła we francuskim porządku prawnym, „Kościół i Prawo" 2013, 2. 
Wielomski A., Kościót w cieniu gilotyny. Katolicyzm francuski wobec Rewolucji (1789-1815), Warszawa 2009.

Wójtowicz-Wcisło M., Dwie władze. Studium z dziejów relacji państwo-Kościół w Meksyku, Kraków 2016.

\section{ABSTRACT}

The reason for writing the text was many controversial statements of the author of the book. The article evaluates the structure, sources, and factual contents of the monograph by Urszula Wasilewicz. The author notes important shortcomings of the work and takes issue with several claims made in the book. Author used the method of analysis and synthesis and the method of individual cases. In this way unfounded some of Urszula Wasilewicz's statements were shown.

Key words: the state, the Catholic Church, relations, legal system

\section{NOTA O AUTORZE}

Przemysław Sołga - doktorant na Wydziale Humanistycznym Uniwersytetu Pedagogicznego w Krakowie. Jego zainteresowania naukowe to: historia Kościoła, historiologia, politologia religii. E-mail: przemyslaw.solga@gmail.com 